\title{
Organic carbon fluxes between a high marsh and estuary, and the inapplicability of the Outwelling Hypothesis
}

\author{
D. I. Taylor *, B. R. Allanson \\ Institute for Water Research, Rhodes University, PO Box 94, Grahamstown, 6140, South Africa
}

\begin{abstract}
Tidal fluxes of total (TOC), dissolved (DOC) and suspended particulate (POC) organic carbon were measured between a high, Sarcocornia-Chenolea salt marsh and Kariega estuary, South Africa. Fluxes were measured over 42 tides, through four ( 7 to $14 \mathrm{~d}$ ) sampling periods. The marsh showed an annual export of $\mathrm{TOC}$ of $+16 \mathrm{~g} \mathrm{C} \mathrm{m}^{-2} \mathrm{yr}^{-1}$, with $80 \%$ of this occurring in dissolved form. The export was equivalent to $6 \%$ of the aerial macrophyte production of the marsh. In both absolute terms, and relative to macrophyte production, the fluxes were similar to those reported for high elevation, Spartina patens and Distichlis spicata marshes on the east coast of the USA. They were, however, an order of magnitude smaller than for most low, Spartina alterniflora marshes. A carbon budget developed for the Kariega marsh showed that respiration (mainly by the sediments and to a lesser extent by resident crabs) accounted for $70 \%$ of marsh production, leaving $30 \%$ for burial or export to the estuary We speculate that the small export was a function of the high elevation of the marsh, and that the Outwelling Hypothesis may be less applicable to high than low marshes.
\end{abstract}

KEY WORDS: Salt marsh High marsh Organic carbon · Fluxes - Production

\section{INTRODUCTION}

Salt marshes are functionally connected to adjoining coastal waters via advective transfers of water and dissolved and particulate material, and movement of nektonic fish and invertebrates. These interactions are fundamental to understanding the roles that salt marshes play in the functioning of coastal waters, and have been the focus of much research over the last 3 decades (early studies reviewed by Nixon 1980, later studies include Roman \& Daiber 1989, Dame et al. 1991. Williams et al. 1992). Based on early studies that showed the elevated primary production of salt marshes, early workers suggested that marshes might be responsible for large-scale exportation of organic material to adjacent waters (Odum \& de la Cruz 1967). In subsequent work, this view has become widely referred to as the Outwelling Hypothesis (Odum 1980, Dame et al. 1986).

\footnotetext{
- Present address: The University of Rhode Island, Graduate School of Oceanography, Narragansett, RI 02882-1197, USA
}

Most studies of these interactions, and of the Outwelling Hypothesis, have been conducted on marshes of the east coast of the USA. Most of these, have, in turn, focused on low elevation, Spartina alterniflora marshes (exceptions include Dankers et al. 1984, Kokkinn \& Allanson 1985, Abd. Aziz \& Nedwell 1986, Baird \& Winter 1992). Far fewer studies have been conducted on high elevation marshes (exceptions include Borey et al. 1983, Jordan \& Correll 1991). High and low marshes have quite different properties, but it is not known how these might affect their interactions with adjoining waters.

Along the east coast of the USA, high elevation marshes are characterized by macrophyte species such as Spartina patens, Distichlis spicata and Juncus sp. The low marshes are typically vegetated by Spartina alterniflora. High marshes occur above mean high water (MHW), while low marshes extend from MHW to mean low water (MLW) (McKee \& Patrick 1988). High marshes are flooded less frequently, and for shorter periods than low marshes. They also support 
different epibenthic microalgal (Sullivan \& Moncreif 1988) and macrofaunal (Teal 1958, Tiner 1974) communities. Authors have suggested that the 2 marsh types might exhibit different patterns of fluxes (Nixon 1982), but too few high marshes have been studied to allow systematic comparison.

The present paper examines the applicability of the Outwelling Hypothesis to the fluxes of organic carbon from a high marsh on the southeast coast of South Africa. Along this coast, the high marshes are vegetated by species such as Sarcocornia perennis (Mill.) A. J. Scott and Chenolea diffusa Thunb. (Day 1981). The low marshes are characterized by monospecific stands of rice grass Spartina maritima (Curtis) Fernald. Baird \& Winter (1992) have measured the fluxes of organic carbon from a low $S$. maritima marsh, but as far as we are aware, no equivalent studies have been conducted for high, Sarcocornia-Chenolea marshes.

\section{STUDY AREA}

The marsh is located in the lower-middle reaches of the Kariega estuary, South Africa $\left(33^{\circ} 40^{\prime} 37^{\prime \prime} \mathrm{S}\right.$, $26^{\circ} 38^{\prime} 46^{\prime \prime}$ E) (Fig. 1). Details of the marsh and estuary

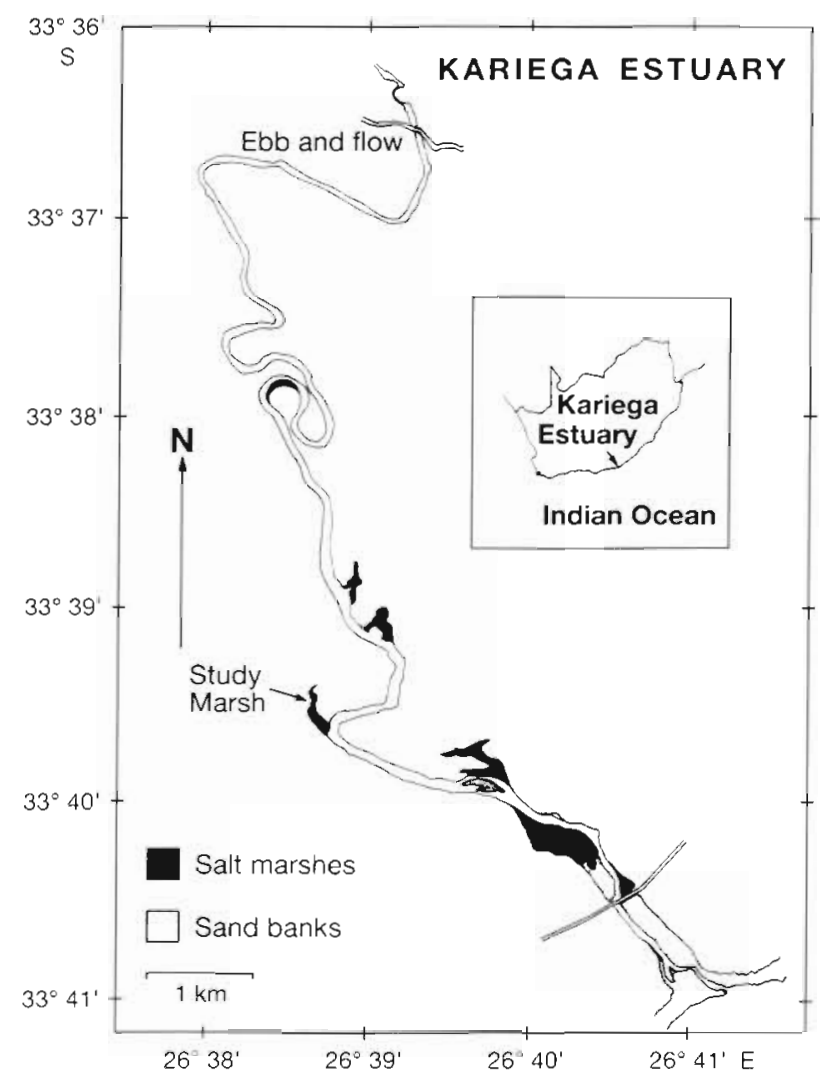

Fig. 1 Location of the Kariega estuary and study marsh in South Africa

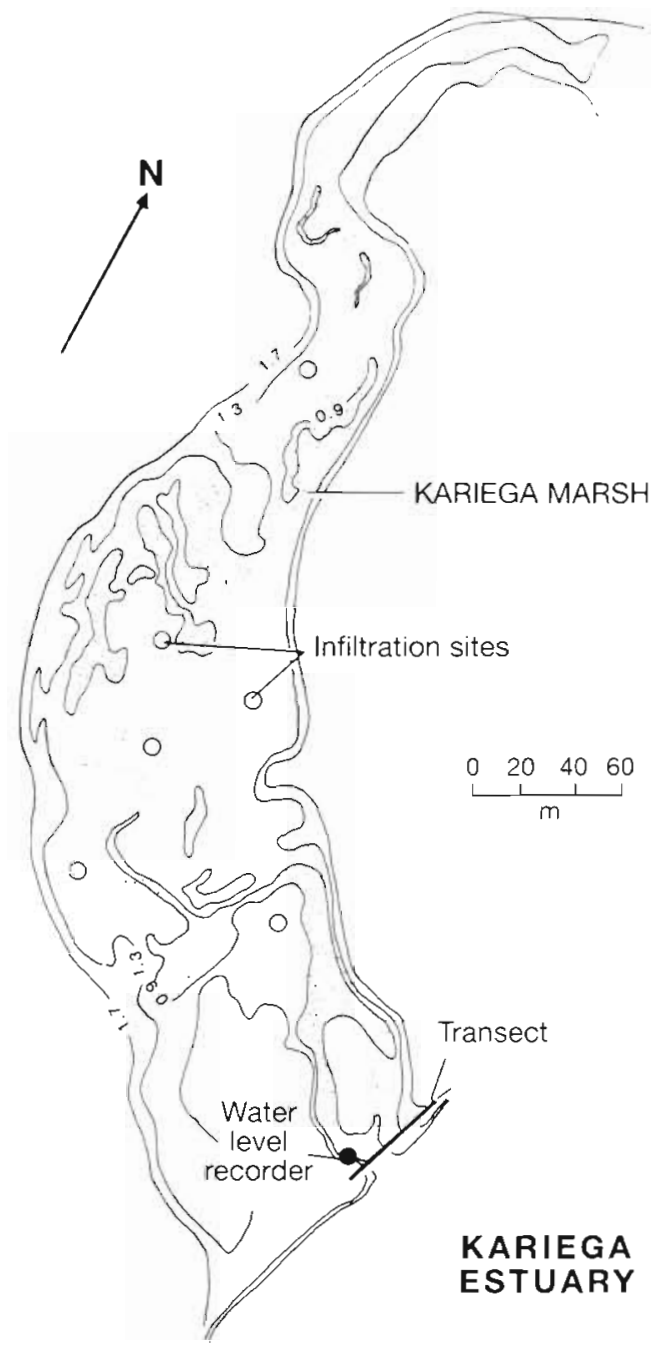

Fig. 2. Topography of the marsh, and location of the transect across which water flow and organic carbon fluxes were measured. Stippled areas indicate tidal creek. Contour interval $=0.40 \mathrm{~m}$. Open circles denote sites at which rates of infiltration were measured

are provided in Taylor (1988) and Allanson \& Read (1987), respectively. The total area of the marsh was 4.2 ha, of which 3.5 ha was accounted for by marsh flats, and the remaining 0.7 ha by tidal creek (Fig. 2). The marsh was termed a high marsh, because vegetation typical of high marshes in this region (Sarcocornia perennis, Chenolea diffusa, Sporobolus virginicus, Atriplex vestita, Limonium scabrum, Salicornia meyerana) covered 3.2 ha (or $76 \%$ ) of the total marsh area. Stands of Spartina maritima, the species typical of local low marshes, covered only 0.3 ha.

The marsh has negligible through flows of freshwater, and the major exchange of water between the marsh and adjacent systems (> $99 \%$ by volume) is with the adjoining estuary. Estuary water enters and drains the marsh through a single narrow channel, which at 
high water is $25 \mathrm{~m}$ wide and $<1.5 \mathrm{~m}$ deep at its junction with the estuary. The dominant tidal signal is semidiurnal (ca $12.5 \mathrm{~h}$ ). Both the tidal creek and the marsh flats are drained almost entirely of surface water each low water (Taylor 1988).

The Kariega estuary is a marine-dominated lagoonlike estuary. It is elongate and sinuous, approximately $18 \mathrm{~km}$ long, with a mean width of $110 \mathrm{~m}$. Because its catchment is semi-arid and impounded, the freshwater inflow into the estuary is small and intermittent. Generally, the water column salinities along the entire length of the estuary matches that of the adjoining ocean (35 psu). During periods of drought, hypersaline (42 psu) conditions may develop in its upper reaches during summer. During the 12 mo of this study, the estuary water column adjacent to the marsh was vertically well mixed, with salinities of 35 psu.

\section{METHODS}

Water flow. A transect was established across the tidal creek at its junction with the estuary (Figs. 2 \& 3). Water flow and fluxes of organic carbon were measured across this transect over 42 tides, over four 7 to 14 d) sampling periods. Each sampling period was located at approximately mid-season in southern hemisphere autumn (6 to 12 May 1984), winter (27 to 31 July and 9 to 17 August 1984), spring (2 to 11 November 1984) and summer (16 to 27 January 1985). The winter sampling period was divided into 2 shorter periods for reasons of logistics. Fluxes during each sampling period were measured over approximately every second tide. On occasion, it was not possible (for reasons of logistics) to sample every second tide. In these situations, an additional tide was missed, and the schedule of sampling alternate tides resumed thereafter.

During each tide, current velocities were measured using Savonius rotors suspended from a manifold constructed across the channel (Fig. 3). The lower threshold velocity of the rotors was $0.01 \mathrm{~m} \mathrm{~s}^{-1}$. The rotors were placed at specific positions in the channel using a graduated pulley system. Measurements were initiated in mid-channel when rising water levels were sufficient to completely cover the rotor. All velocities were measured at mid-depth. As water levels rose, velocities were measured at between 1 and 7 additional positions across the channel. The velocities were measured at 15 min intervals. When water levels in the tidal creek were less than $1.4 \mathrm{~m}$ above mean sea level (MSL), velocities were measured across the channel at positions $1.0 \mathrm{~m}$ apart. When water levels exceeded this, the distance between positions was (for reasons of logistics) increased to $2.0 \mathrm{~m}$.
The velocities at each position were considered to represent the average velocity for a sector extending from the water surface to sediments, and 0.5 or $1.0 \mathrm{~m}$ (depending on water level) on either side of the rotor. The sectors are shown by vertical dashed lines for 3 representative tides in Fig. 3. The cross-sectional area of the water across the transect, and in each of the sectors, was measured planimetrically. The overall sampling strategy emphasized cross-channel rather than vertical characterization of water flow. This strategy was adopted because pilot surveys (Taylor 1988) showed that, at the spatial resolution measured by the rotors, the velocity changes across channel were an order of magnitude greater than those vertically through the water column. For instance, during a tide reaching $1.1 \mathrm{~m}$ above $\mathrm{MSL}$, current velocities across channel spanned 0 to $0.22 \mathrm{~m} \mathrm{~s}^{-1}$, while velocities vertically through the water column varied by 0.02 to $0.04 \mathrm{~m} \mathrm{~s}^{-1}$.

During each tide, the water level in the creek was recorded using an A. Ott (Model HBe 20.110.0.1) horizontal water level recorder deployed in the creek at the marsh-estuary junction (Fig, 2). The recorder was calibrated to MSL, to within $0.01 \mathrm{~m}$, by a qualified surveyor Continuous water level recordings were conducted at this site for 12 mo (1 February 1984 to 31 January 1985) that spanned the 4 periods during which organic carbon fluxes were measured. At the start

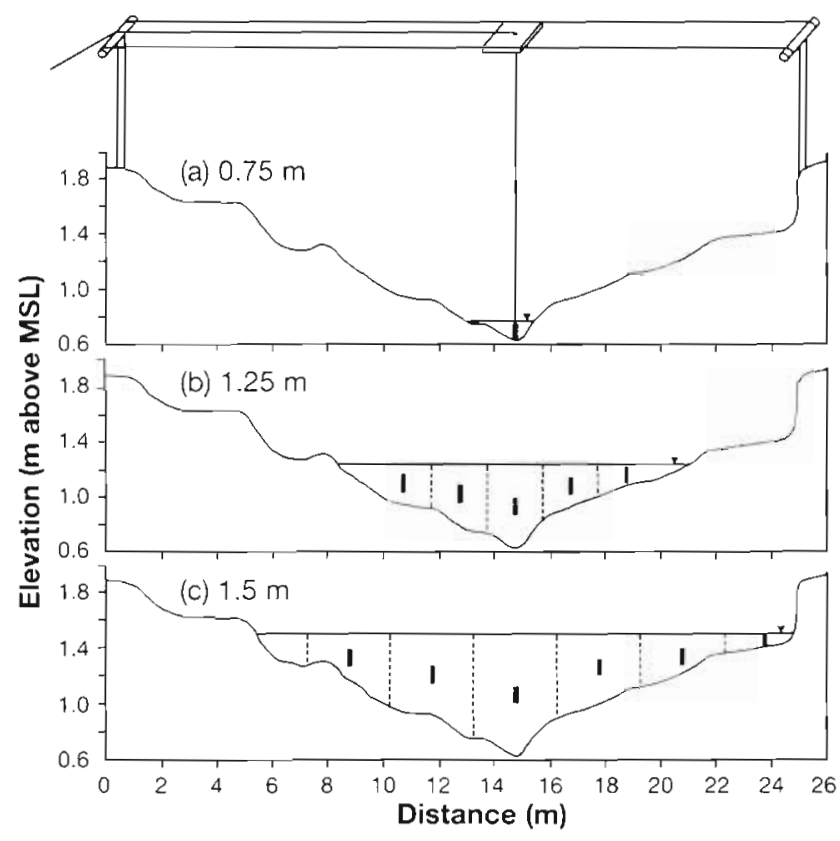

Fig. 3. Cross-section of the transect for 3 tides that attained maximum elevations of (a) $0.75 \mathrm{~m}$ above MSL, (b) $1.25 \mathrm{~m}$ above MSL, and (c) $1.50 \mathrm{~m}$ above MSL. Thick vertical bars denote positions at which current velocities were measured. Vertical dashed lines denote sectors 
(February 1984) and end (February 1985) of the 12 mo, the cross-sectional profile of the creek was surveyed at $0.2 \mathrm{~m}$ intervals. Comparison of before- and afterprofiles indicated that no correction was necessary for erosion or deposition.

The surface area of marsh inundated each tide was measured over 17 tides. During each of these tides, stakes were hammered into the marsh at the outer boundary of the flood-water, at high water. The locations of the stakes were then plotted onto a map of the marsh, and the area inundated determined planimetrically. A curvilinear relationship was established between the area inundated $(y)\left(\mathrm{m}^{2}\right)$ and the maximum water level achieved by each tide $(x)$ (m above MSL), thus: $y=21.78 x^{2}-12.31 x-1.33, r^{2}=0.976$. This relationship was used to express the estimates of net fluxes as net fluxes per square meter of marsh inundated.

Rates of water infiltration into the marsh surface were measured using a modification of the shallowwell, pump-in method of Boersma (1965). Two concentric metal cylinders, $0.3 \mathrm{~m}$ high, with diameters of 0.3 and $0.5 \mathrm{~m}$, were embedded $0.3 \mathrm{~m}$ into the marsh surface, at low tide at 6 locations (Fig. 2). Water levels were maintained at $0.15 \mathrm{~m}$ depth in both cylinders using header tanks, and rates of volume decrease in the header tank feeding the inner cylinder was used as a measure of infiltration rate. The measurements were conducted only on the marsh flats, because during tidal inundation groundwater in the tidal creek rises through the sediments and reaches the sediment surface at the same time as does surface flow (Taylor 1988). It was therefore assumed that in the tidal creek, rates of infiltration were probably negligible.

Water column organic carbon. Water samples for organic carbon analyses were collected in midchannel, at mid-depth, initially and then at $30 \mathrm{~min}$ intervals through each tide. Initial water column samples were collected at the same time the first velocity readings were taken. Because subsequent velocity measurements were made at 15 min intervals, and the organic carbon concentrations measured every $30 \mathrm{~min}$, carbon concentrations for the intervening 15 min were estimated by interpolation. Water samples were collected using a $75 \mathrm{ml}$ syringe sampler (Liptrot 1978). Four water column samples were collected every 30 min: 2 were left unfiltered for total organic carbon (TOC) analysis, and the remaining two filtered (prerinsed, pre-ashed Whatman GF/F filters) for estimation of dissolved organic carbon (DOC). All samples were stored on ice in the dark for up to $1 \mathrm{~h}$, before being frozen in a field laboratory.

TOC and DOC concentrations were determined using a Beckman 915B Total Organic Carbon Ana- lyzer, after removal of inorganic carbon from the water samples by acid sparging. Precision of the analytical technique, as applied, and expressed as percentage coefficients of variance, was between 3 and $6 \%$ at DOC concentrations of 3 to $10 \mathrm{mg} \mathrm{Cl}^{-1}(\mathrm{n}=9)$. The particulate organic carbon (POC) concentrations were determined as the difference in mean $(n=2)$ concentrations between the unfiltered (TOC) and filtered (DOC) samples.

Computations. All computations were based on Kjerfve (1979), and where possible notations used by this author have been maintained. Thus, positive values denote net fluxes (or exports) from marsh, while negative values denote net fluxes (or imports) onto marsh. For each tide, instantaneous flow per sector, $Q(t),\left(\mathrm{m}^{3} \mathrm{~s}^{-1}\right)$, at time $t$ was calculated as:

$$
Q(t)=V(t) \times A(t)
$$

where $V(t)$ is velocity at mid-depth at the position within the sector $\left(\mathrm{m} \mathrm{s}^{-1}\right)$ at time $t$, and $A(t)$ is crosssectional area of the sector $\left(\mathrm{m}^{2}\right)$ at $t$. For each tide, $Q(t)$ values were computed initially and then every $15 \mathrm{~min}$.

Instantaneous flows through the entire cross-section, $Q_{T},\left(\mathrm{~m}^{3} \mathrm{~s}^{-1}\right)$, were calculated by summing the $Q(t)$ values at time $t$ for $m$ numbers of sectors, thus:

$$
Q_{T}=\sum_{i=1}^{m} Q(t)_{i}
$$

where $i$ is a width counter.

The net flow over the tidal cycle, $Q_{\text {TIDE, }}$ was then computed by summing the $Q_{T}$ values for each time interval, thus:

$$
Q_{\mathrm{TIDE}}=\sum_{i=1}^{m} Q_{\mathrm{T}}
$$

The instantaneous fluxes per sector, $F(t)$, were calculated for TOC, DOC and POC as follows:

$$
F(t)=Q(t) C(t) \rho(t)
$$

where $Q(t)$ is instantaneous sector flow $\left(\mathrm{m}^{3} \mathrm{~s}^{-1}\right)$ at time $t, c(t)$ is concentration ( $\mathrm{mgC} \mathrm{kg}{ }^{-1}$ ) at time $t$, and $\rho$ is water density assumed to be $1020 \mathrm{~kg} \mathrm{~m}^{-3}$ (Kjerfve 1979). The $F(t)$ values for each $15 \mathrm{~min}$ were then used to estimate the cross-sectional net fluxes for the entire tide, $F_{\text {TIDE, }}$ by substituting $F$ for $Q$ in Eqs. (2) \& (3).

\section{RESULTS}

The mean ( $\pm \mathrm{SD}$ ) net flow $\left(Q_{\text {TIDE }}\right)$ for all 42 tides combined amounted to a net retention by the marsh of $-11 \pm 45 \mathrm{~m}^{3}$ tide $^{-1}(\mathrm{n}=42)$ (Table 1$)$. (Note: negative values denote net imports; positive values, net ex- 
Table 1 Mean flow properties for tides during each of the 4 sampling periods. - values: net import onto marsh. + values: net export to estuary. Rel.: relative

\begin{tabular}{|c|c|c|c|c|c|c|c|}
\hline Date & $\begin{array}{l}\text { Max. elevation } \\
\text { achieved by tide } \\
\text { (m above MSL) }\end{array}$ & $\begin{array}{l}\text { Marsh area } \\
\text { inundated } \\
\left(\times 10^{3} \mathrm{~m}^{2}\right)\end{array}$ & $\begin{array}{l}\text { Flood-tide } \\
\text { flow } \\
\qquad\left(\mathrm{m}^{3}\right)\end{array}$ & $\begin{array}{c}\text { Ebb-tide } \\
\text { flow } \\
\left(\mathrm{m}^{3}\right)\end{array}$ & $\begin{array}{c}\text { Net } \\
\text { flow } \\
\left(\mathrm{m}^{3} \text { tide }^{-1}\right)\end{array}$ & $\begin{array}{l}\text { Rel. magnitude } \\
\text { of net flow: } \\
\qquad(\%)\end{array}$ & $\begin{array}{l}\text { Areal net flow }{ }^{b} \\
\left(\times 10^{-3} \mathrm{~m}^{3} \mathrm{~m}^{-2} \text { tide }^{-1}\right)\end{array}$ \\
\hline Autumn $(n=7)$ & $1.0 \pm 0.1$ & $8.5 \pm 5.7$ & $-510 \pm 432$ & $510 \pm 466$ & $+0.1 \pm 39$ & $7 \pm 3.7$ & $-1.9 \pm 3.7$ \\
\hline Winter $(n=14)$ & $0.95 \pm 0.1$ & $6.0 \pm 3.0$ & $-409 \pm 296$ & $408 \pm 288$ & $-1 \pm 24$ & $6 \pm 3$ & $-0.7 \pm 4.2$ \\
\hline Spring $(n=10)$ & $0.94 \pm 0.13$ & $6.2 \pm 4.4$ & $-447 \pm 426$ & $421 \pm 387$ & $-26 \pm 43$ & $7 \pm 7$ & $-3.7 \pm 4.0$ \\
\hline Summer $(n=11)$ & $1.13 \pm 0.13$ & $12.5 \pm 5.3$ & $-975 \pm 548$ & $956 \pm 547$ & $-18 \pm 69$ & $5 \pm 4$ & $-1.8 \pm 4.6$ \\
\hline All $(n=42)$ & $1.01 \pm 0.14$ & $8.18 \pm 5.06$ & $-581 \pm 469$ & $570 \pm 463$ & $-11 \pm 45$ & $6 \pm 4$ & $-1.6 \pm 4.3$ \\
\hline
\end{tabular}

ports.) Expressed per square meter of marsh inundated, the mean net flow was $-1.6 \pm 4.3 \times 10^{-3} \mathrm{~m}^{3}$ tide $^{-1}$. The net flow for individual tides amounted to between 0 and $18 \%$ of flood-tide flow, averaging $6.5 \pm$ $4.5 \%$ for all tides.

The mean rate of water infiltration into the marsh sediments was $0.11 \pm 0.11 \times 10^{-3} \mathrm{~m}^{3} \mathrm{~m}^{-2} \mathrm{~h}^{-1}(\mathrm{n}=6)$. Assuming the marsh flats were inundated for an average of $2 \mathrm{~h}$ per tide (Taylor 1988), the quantity of water potentially retained by the marsh sediments was in the order of $0.32 \times 10^{-3} \mathrm{~m}^{3} \mathrm{~m}^{-2}$ tide $\mathrm{e}^{-1}$. This is equivalent to approximately $20 \%$ of the average net flow $\left(-1.6 \times 10^{-3} \mathrm{~m}^{3} \mathrm{~m}^{-2}\right.$ tide $\left.^{-1}\right)$ onto the marsh.

For all 4 sampling periods combined, the marsh showed an annual export (positive values) of TOC to the estuary (Table 2). Approximately $80 \%$ of the export occurred in the dissolved form. The average $( \pm \mathrm{SD})$ net flux of DOC was $+463 \pm 962 \mathrm{~g} \mathrm{C}^{\text {tide }}{ }^{-1}$. For $P O C$, the equivalent value was $+105 \pm 340 \mathrm{gC} \mathrm{tide}^{-1}$. If expressed per square meter of marsh inundated, the fluxes amounted to $+48 \pm 112 \mathrm{mg} \mathrm{C} \mathrm{m}^{-2}$ tide $^{-1}$ for DOC, and $+8 \pm 44 \mathrm{mg} \mathrm{C} \mathrm{m}^{-2}$ tide $^{-1}$ for $\mathrm{POC}$.

With the exception of POC in autumn, the marsh exported both fractions during all 4 sampling periods (Table 2). During each of the sampling periods, the sizes of the fluxes varied widely between tides, as shown by the large standard deviations of the means. Because of this variability, a seasonal pattern of fluxes could not be discerned. The exports of DOC may have been greater during summer and autumn than during winter and spring, but the differences between means were not statistically significant.

\section{DISCUSSION}

Several lines of evidence suggest that the flow and carbon flux estimates are realistic. The fact that the marsh showed an overall net retention of water, and that the retention was small, agrees with our current understanding of the hydrodynamics of the marsh. It is not fed by surface streams, and its groundwater flow is less than $1 \%$ of its surface tidal flow (Taylor 1988). The marsh is also located in a semi-arid region, and received no heavy precipitation during the 4 sampling periods. Infiltration apparently accounted for about $20 \%$ of net flow, and retention in the surface depressions on the marsh, a further 0 to $15 \%$ (Taylor 1988). Presumably the remaining 65 to $85 \%$ of net flow is attributable to evaporative losses, drainage into crab burrows, and measurement error.

The fact that water flow is the dominant term in estimating material fluxes from marshes (Roman 1984), and the estimates of net flow varied from 0 and $18 \%$ of flood-tide flow, indicates that the error of the carbon

Table 2. Average ( \pm SD) fluxes of DOC, POC and TOC between the marsh and estuary. Symbols as in Table 1. n: number of tides

\begin{tabular}{|c|c|c|c|c|c|c|c|c|c|}
\hline \multirow[t]{2}{*}{ Date } & \multicolumn{3}{|c|}{$\begin{array}{l}\text { Net flux } \\
\left(\mathrm{g} C \text { tide }^{-1}\right)\end{array}$} & \multicolumn{3}{|c|}{$\begin{array}{l}\text { Net flux per } \mathrm{m}^{2} \text { marsh inundated } \\
\left(\mathrm{mg} \mathrm{C} \mathrm{m}^{-2} \text { tide }^{-1}\right)\end{array}$} & \multicolumn{3}{|c|}{$\begin{array}{l}\text { Net flux per } \mathrm{m}^{2} \text { entire marsh } \\
\left(\mathrm{mg} \mathrm{C} \mathrm{m}^{-2} \text { tide }^{-1}\right)\end{array}$} \\
\hline & $\mathrm{DOC}$ & $\mathrm{POC}$ & TOC & DOC & POC & TOC & DOC & POC & TOC \\
\hline Autumn $(n=7)$ & $+986 \pm 584$ & $-66 \pm 233$ & $+920 \pm 594$ & $+117 \pm 47$ & $-10 \pm 36$ & $+107 \pm 74$ & $+28 \pm 16$ & $-2 \pm 7$ & $+26 \pm 17$ \\
\hline Winter $(n=14)$ & $+46 \pm 517$ & $+32 \pm 125$ & $+78 \pm 572$ & $+8 \pm 94$ & $+3 \pm 22$ & $+11 \pm 100$ & $+2 \pm 13$ & $+1 \pm 3$ & $+3 \pm 14$ \\
\hline Spring $(\mathrm{n}=10)$ & $+79 \pm 466$ & $+165 \pm 222$ & $+244 \pm 526$ & $+39 \pm 71$ & $+24 \pm 55$ & $+63 \pm 103$ & $+2 \pm 13$ & $+5 \pm 6$ & $+7 \pm 15$ \\
\hline Summer $(n=11)$ & $+1008 \pm 1398$ & $+255 \pm 540$ & $+1263 \pm 1667$ & $+62 \pm 97$ & $+12 \pm 50$ & $+74 \pm 115$ & $+29 \pm 38$ & $+7 \pm 15$ & $+36 \pm 46$ \\
\hline All $(n=42)$ & $+463 \pm 962$ & $+105 \pm 340$ & $+568 \pm 1102$ & $+48 \pm 112$ & $+8 \pm 44$ & $+56 \pm 106$ & $+13 \pm 27$ & $+3 \pm 10$ & $+16 \pm 31$ \\
\hline
\end{tabular}


flux estimates was probably also in the order of 0 to $18 \%$. This is considered acceptable in view of the wave action observed at times at the mouth of the marsh, and the high detection limit of the Savonius rotors relative to current velocities in the creek. As for most studies, the flux estimates do not include transfers that might have occurred as a result of floating wrack, surface films, bedload transport, and movement of nekton. The estimates also exclude the fluxes that might have occurred during storms (Chalmers et al. 1985, Roman \& Daiber 1989).

Notwithstanding these shortcomings, the annual flux estimates (Table 2) are based on measurements of more tides $(n=42)$ than in most other studies (exceptions include Woodwell et al. 1979, Jordan \& Correll 1991). They are also directly comparable with the types of measurements of DOC and POC fluxes that have been conducted for most marshes (Table 3). The annual export of TOC from the Kariega marsh amounted to $+16 \mathrm{gC} \mathrm{m}^{-2} \mathrm{yr}^{-1}$. This is remarkably similar to the few flux estimates that are available for the high Spartina patens and Distichlis spicata marshes of the east coast of the USA. Borey et al. (1983) documented TOC exports of $+25 \mathrm{gC} \mathrm{m}^{-2} \mathrm{yr}^{-1}$ from Coon Creek, a high marsh in Texas, USA. Jordan \&
Correll (1991) reported a similar export of $+49 \mathrm{gC}$ $\mathrm{m}^{-2} \mathrm{yr}^{-1}$ from a high marsh in the Rhode River, Maryland, USA.

The fluxes from the Kariega and other high marshes were, in turn, an order of magnitude smaller than the fluxes reported for most low, Spartina alterniflora marshes. While certain low marshes have been shown to import TOC, mainly as POC (Flax Pond, New York, USA, Woodwell et al. 1979; Dollard marsh, The Netherlands, Dankers et al. 1984), most apparently export TOC, mainly as DOC. For these, the exports have generally fallen between +100 and $+200 \mathrm{gC} \mathrm{m}^{-2} \mathrm{yr}^{-1}$ (Axelrad et al. 1976, Roman \& Daiber 1989, Dame et al. 1991, Williams et al. 1992), but in certain cases, have been as high as $+450 \mathrm{~g} \mathrm{C} \mathrm{m}^{-2} \mathrm{yr}^{-1}$ (Dame et al. 1986)

Data that are comparable to our estimates of TOC fluxes are not available for other marshes on the South African coast. Flux estimates are available for low Spartina maritima marshes in the nearby Swartkops estuary (Pierce 1979, Baird \& Winter 1992), but these do not include estimates of the fluxes of DOC. For POC, the small export from the Kariega marsh $(3 \mathrm{gC}$ $\mathrm{m}^{-2} \mathrm{yr}^{-1}$ ) is probably not significantly different from the small import of $0.001 \mathrm{gC} \mathrm{m}^{-2} \mathrm{yr}^{-1}$ reported for the Swartkops marsh (Baird \& Winter 1992).

Table 3. Summary of organic carbon fluxes from salt marshes, and comparison of TOC fluxes with net aerial primary production. Because patterns of fluxes of DOC and POC can be different, and certain studies measured only one, only the data from those studies that measured both components are included. nd: not determined. na: not applicable. - values: net imports, + values: net exports

\begin{tabular}{|c|c|c|c|c|c|c|c|}
\hline \multirow[t]{2}{*}{ System } & \multicolumn{3}{|c|}{$\begin{array}{l}\text { Organic carbon flux } \\
\qquad\left(\mathrm{gC} \mathrm{m}^{-2} \mathrm{yr}^{-1}\right)\end{array}$} & \multirow{2}{*}{$\begin{array}{c}\text { Net aerial } \\
\text { primary } \\
\text { production } \\
\left(\mathrm{g} C \mathrm{~m}^{-2} \mathrm{yr}^{-1}\right)\end{array}$} & \multirow{2}{*}{$\begin{array}{l}\text { TOC export } \\
\text { as \% of net } \\
\text { aerial primary } \\
\text { production }\end{array}$} & \multirow[t]{2}{*}{ Form of marsh } & \multirow[t]{2}{*}{ Source } \\
\hline & DOC & POC & TOC & & & & \\
\hline $\begin{array}{l}\text { Ware Creek, } \\
\text { Virginia, USA }\end{array}$ & +80 & +35 & +115 & 599 & 19 & Spartina alterniflora & Axelrad et al. (1976) \\
\hline $\begin{array}{l}\text { Carter Creek, } \\
\text { Virginia, USA }\end{array}$ & +25 & +116 & +142 & 599 & 24 & Spartina alterniflora & Axelrad et al. (1976) \\
\hline $\begin{array}{l}\text { Flax Pond, } \\
\text { New York, USA }\end{array}$ & +8 & -61 & -53 & 372 & na & Spartina alterniflora & Woodwell et al. (1979) \\
\hline $\begin{array}{l}\text { Canary Creek, } \\
\text { Delaware, USA }\end{array}$ & +104 & +55 & +159 & 252 & 63 & Spartina alterniflora & Roman \& Daiber (1989) \\
\hline $\begin{array}{l}\text { Coon Creek, } \\
\text { Texas, USA }\end{array}$ & +21 & +4 & +25 & $550-900$ & $3-5$ & $\begin{array}{l}\text { Spartina patens } \\
\text { Distichlis spicata }\end{array}$ & Borey et al. (1983) \\
\hline $\begin{array}{l}\text { High Marsh, } \\
\text { Rhode River, } \\
\text { Maryland, USA }\end{array}$ & +43 & +14 & $\begin{array}{l}+57 \\
+49\end{array}$ & nd & nd & $\begin{array}{l}\text { Spartinapatens } \\
\text { Distichlis spicata }\end{array}$ & $\begin{array}{l}\text { Jordan et al. (1983) } \\
\text { Jordan \& Correll (1991) }\end{array}$ \\
\hline $\begin{array}{l}\text { Ems-Dollard Marsh, } \\
\text { The Netherlands }\end{array}$ & +15 & -140 & -125 & 500 & na & $\begin{array}{l}\text { Puccinellietum maritima, } \\
\text { Spartina anglica }\end{array}$ & Dankers et al. (1984 \\
\hline $\begin{array}{l}\text { North Inlet, South } \\
\text { Carolina, USA }\end{array}$ & +328 & +128 & +456 & 1059 & na & Spartina alterniflora & Dame et al. (1986) \\
\hline $\begin{array}{l}\text { Bly Creek, South } \\
\text { Carolina, USA }\end{array}$ & $\begin{array}{l}+250 \\
+272\end{array}$ & $\begin{array}{l}-31 \\
-30\end{array}$ & $\begin{array}{l}+219 \\
+242\end{array}$ & $\begin{array}{l}1028^{a} \\
1028^{a}\end{array}$ & $\begin{array}{l}21 \\
24\end{array}$ & Spartina alterniflora & $\begin{array}{l}\text { Williams et al. (1992) } \\
\text { Dame et al. (1991) }\end{array}$ \\
\hline $\begin{array}{l}\text { Kariega Marsh, } \\
\text { South Africa }\end{array}$ & $+13^{\mathrm{a}}$ & $+3^{u}$ & $+16^{a}$ & $200-300$ & $5-8$ & $\begin{array}{l}\text { Spartina perennis, } \\
\text { Chenoled diffusa }\end{array}$ & Present study \\
\hline
\end{tabular}


Several factors may account for the relatively small combined export of DOC and POC from the Kariega marsh. Because of the vertical elevation and topography of the marsh, the area of the marsh inundated each tide was small. During tides that reached the average maximum elevation for all tides inundating the marsh (1.0 m above MSL), only 0.5 ha (or $12 \%$ ) of the total marsh area was inundated. Thus, for most tides only a small area of the marsh surface was available for exchanges of organic carbon with the overlying water.

The aerial net production of the marsh $\left(300 \mathrm{gC} \mathrm{m}^{-2}\right.$ $\mathrm{yr}^{-1}$, Taylor \& Allanson 1993) was also small compared to Spartina alterniflora marshes (500 to $2500 \mathrm{~g} \mathrm{C} \mathrm{m}^{-2}$ $\mathrm{yr}^{-1}$, Turner 1976), and this may have set an upper limit on the quantity of carbon available for export. While this explanation may have applied to the Kariega marsh, it may not explain the small carbon fluxes documented from high $S$. patens and Distichlis spicata marshes which have rates of production (500 to $1500 \mathrm{gC}$ $\mathrm{m}^{-2} \mathrm{yr}^{-1}$ ) comparable to low marshes (Turner 1976).

The TOC exports from the Kariega marsh amounted to about $6 \%$ of its macrophyte production, and is among the lowest percentage losses reported (Table 3). It is similar to the $3 \%$ for Coon Creek, the high marsh studied by Borey et al. (1983), but is much smaller than the 21 to $24 \%$ (Dame et al. 1991, Williams et al. 1992), and $43 \%$ (Dame et al. 1986) reported for low marshes. This would suggest that for the Kariega marsh, and possibly for other high marshes such as Coon Creek, a relatively large proportion of macrophyte production is 'consumed' on the marsh by respiratory or burial processes.

The carbon budget for the Kariega marsh (Table 4) indicates that respiration was the larger of the 2 pathways of carbon consumption. Respiration by marsh sediments $\left(+189 \mathrm{gC} \mathrm{m}^{-2} \mathrm{yr}^{-1}\right)$, and to a lesser extent by marsh crabs $\left(+27 \mathrm{gC} \mathrm{m}^{-2} \mathrm{yr}^{-1}\right)$, accounted for about $70 \%$ of macrophyte production, leaving less than $30 \%$ for export or burial. This value of $30 \%$ is less than half the approximately $76 \%$ calculated to be available for low elevation, Bly Creek marsh (Dame et al. 1986). If this difference is more generally applicable, it would suggest that more carbon is channeled to the atmosphere, and less to adjoining waters, on high than low marshes.

At this time, we speculate that this difference between the 2 marsh types may be a function of their different elevations and degrees of water exchange with adjoining systems. Because of the high elevation of the Kariega marsh, tidal water was confined to its narrow tidal creek during almost half ( $43 \%$ ) of all tides (Taylor 1988). During these tides the vegetated marsh flats remained totally exposed. Even during tides that reached the average maximum tide elevation of $1.0 \mathrm{~m}$
Table 4. Comparison of the net fluxes of total organic carbon (TOC) with the other components of the annual carbon budget for the Kariega marsh. - values: import or net uptake (production). + values: export or net loss (respiration). Values prorated over entire marsh

\begin{tabular}{|lc|}
\hline Process & Rate $\left(\mathrm{g} \mathrm{m}^{-2} \mathrm{yr}^{-1}\right)$ \\
\hline TOC net flux & +16 \\
Macrophyte net production & \\
All marsh & -300 \\
Marsh flats & -300 \\
Tidal creek & $<1$ \\
Epibenthic net production & \\
All marsh & +189 \\
Marsh flats & +201 \\
Tidal creek & -12 \\
Crab respiration & \\
All marsh & +27 \\
Marsh flats & +23 \\
Tidal creek & +4 \\
a Taylor \& Allanson (1993) & \\
\hline
\end{tabular}

above MSL, only 0.5 ha of the vegetated marsh flats were inundated. Thus, for most tides, and for all periods between tides, the marsh was exposed to the atmosphere, facilitating exhanges of gaseous carbon with the atmosphere rather than organic carbon with the estuary.

The limited inundation also means that the surface sediments of the marsh flats were inundated too infrequently to support high epibenthic microalgal populations. Primary production of marsh epibenthic microalgae has been shown to be correlated with sediment moisture content (Sullivan \& Moncreif 1988). The dry sediments of the marsh flats were heterotrophic, while the moister tidal creek sediments were autotrophic (Table 4) (Taylor \& Allanson 1993). Because of the much larger area of the marsh flats, the sediments of the marsh as a whole were heterotrophic, channeling carbon to the atmosphere.

On the marsh flats, the Spartina perennis and Chenolea diffusa plants also formed dense horizontal canopies, in much the same way that $S$. patens and Distichlis spicata do on north temperate high marshes (Borey et al. 1983). These types of canopies have a greater shading effect than vertical canopies of, for example, S. alterniflora (Blum 1968). They are also more likely to trap detached plant material than vertical canopies (Borey et al. 1983), in turn, facilitating decomposition within the marsh rather than in the adjoining estuary.

Acknowledgements. The research was funded by a Doctoral Bursary from the Foundation for Research Development, Council for Scientific Research, Republic of South Africa. Thanks are extended to L. Christmas for technical assistance. 


\section{LITERATURE CITED}

Abd. Aziz, S. A., Nedwell, D. B. (1986). The nitrogen cycle of an east coast U.K. salt marsh: II Nitrogen fixation, nitrification, denitrification, tidal exchange. Estuar. coast. Shelf Sci. 22: $689-704$

Allanson, B. R., Read, G. H. L. (1987). The response of estuaries along the south eastern coast of southern Africa to marked variation in freshwater inflow. Special Report No. 2/87 of Institute for Freshwater Studies, Rhodes University, Grahamstown

Axelrad, D. M., Moore, K. A., Bender, M. E. (1976). Nitrogen, phosphorus and carbon flux in Chesapeake Bay marshes. Virginia Water Research Center Bulletin 79, Blacksburg

Baird, D., Winter, P. E. D. (1992). Flux of inorganic nutrients and particulate carbon between a Spartina maritima salt marsh and the Swartkops Estuary, Eastern Cape. S. Afr. J. aquat. Sci. 18: $64-73$

Blum, J. L. (1968). Salt marsh Spartinas and associated algae. Ecol. Monogr. 38: 199-221

Boersma, L. (1965). Field measurement of hydraulic conductivity below a water table. In: Black, C. A. (ed.) Methods of soil analysis, Part 1. American Society of Agronomy, Madison, p. 222-233

Borey, R. B., Harcombe, P. A., Fisher, F. M. (1983). Water and organic carbon fluxes from an irregularly flooded brackish marsh on the upper Texas coast, U.S.A. Estuar. coast. Shelf Sci. 16: 379-402

Chaimers, A. G., Wiegert, R. G., Wolf, P. L. (1985). Carbon balance in a salt marsh: interactions of diffusive export, tidal deposition, and rainfall caused erosion. Estuar. coast. Shelf Sci. 21: 757-768

Dame, R. F., Chrzanowski, I., Bildstein, K., Kjerfve, B. Mckellar, H., Nelson, D., Spurrier, J., Stancyk, S., Stevenson, H., Vernberg, J., Zingmark, R. (1986). The outwelling hypothesis and North Inlet, South Carolina. Mar. Ecol, Prog. Ser. 33: 217-229

Dame, R. F, Spurrier, J., Williams, T M., Kjerfve, B., Zingmark, R. G., Wolaver, T G., Chrzanowski, T. H., McKellar, H. N., Vernberg, F. J. (1991). Annual material processing by a salt marsh-estuarine basin in South Carolina, USA. Mar. Ecol. Prog. Ser. 72: 153-166

Dankers, N., Binsbergen, M., Zegers, K., Laane, R., Rutgers, van der Loeff, M. (1984). Transportation of water, particulate and dissolved organic and inorganic matter between a salt marsh and the Ems-Dollard estuary, The Netherlands Estuar. coast. Shelf Sci. 19: 143-165

Day, J. H. (1981). Estuarine ecology with specific reference to Southern Africa. Balkema, Cape Town

Jordan, T E., Correll, D. L. (1991). Continuous automated sampling of tidal exchanges of nutrients by brackish marshes. Estuar. coast. Shelf Sci. 32: 527-545

Jordan, T E., Correll, D. L., Whigham, D. F. (1983). Nutrient flux in the Rhode River: tidal exchange of nutrients by brackish marshes. Estuar. coast. Shelf Sci. 17: 651-667

Kjerfve, B. (1979). Measurement and analysis of water current, temperature, salunity and density. In: Dyer, K. R. (ed.) Estuarine hydrography and sedimentation. Cambridge University Press, Cambridge, p. 186-226

Kokkinn, M. J., Allanson, B. R. (1985). On the flux of organic carbon in a tidal salt marsh, Kowie River estuary, Port Alfred, South Africa. S. Afr. J. Sci. 81: 613-617
Liptrot, M. R. M. (1978). Community metabolism and phosphorus dynamics in a seasonally closed South African estuary. M.Sc. dissertation, Rhodes University, Grahamstown

McKee, K. L., Patrick, W. H. Jr (1988). The relationship of smooth cordgrass (Spartina alterniflora) to tidal datums: a review. Estuaries 11. 143-151

Nixon, S. W. (1980). Between coastal marshes and coastal waters - a review of twenty years of speculation and research on the role of salt marshes in estuarine productivity and water chemistry. In: Hamilton, R., MacDonald, K. B. (eds.) Estuarine and wetland processes. Plenum Press, New York, p. 437-525

Nixon, S. W. (1982). The ecology of New England high salt marshes: a community profile. U.S. Fish and Wildlife Service, Office of Biological Services, Washington, DC FWS/OBS - 81/55

Odum, E. P. (1980). The status of three ecosystem-level hypotheses regarding salt marsh estuaries: tidal subsidy, outwelling and detritus-based food chains. In: Kennedy, V (ed.) Estuarine perspectives. Academic Press, New York, p. $437-525$

Odum, E. P., de la Cruz, A. A. (1967). Particulate organic detritus in a Georgia salt marsh-estuarine ecosystem. In: Lauff, G. H. (ed.) Estuaries. AAAS, Publ. No. 83, Washington, DC, p. $383-388$

Pierce, S. M. (1979). The contribution of Spartina maritima (Curtis) Fernald to the primary production of the Swartkops estuary. M.Sc. thesis, Rhodes University, Grahamstown

Roman, C. T. (1984). Estimating water volume discharge through salt marsh tidal channels: an aspect of material exchange. Estuaries 7: 259-264

Roman, C. T., Daiber, F. C. (1989). Organic carbon flux through a Delaware Bay salt marsh: tidal exchange, particle size distribution, and storms. Mar. Ecol. Prog Ser. 54: 149-156

Sullivan, M. J., Moncreiff, C. A. (1988). Primary production of edaphic algal communities in a Mississippi salt marsh. J. Phycol. 24: 49-58

Taylor, D. I. (1988). Tidal exchanges of carbon, nitrogen and phosphorus between a Sarcocornia salt marsh and the Kariega estuary, and the role of salt marsh brachyura in this transfer. Ph.D. thesis, Rhodes University, Grahamstown

Taylor, D. I., Allanson, B. R. (1993). Impacts of dense crab populations on carbon exchanges across the surface of a salt marsh. Mar. Ecol. Prog. Ser. 101 119-129

Teal, J. M. (1958). Distribution of fiddler crabs in Georgia salt marshes. Ecology 39: 185-193

Tiner, R. W. (1974). The ecological distribution of the invertebrate macrofauna in the Cottrell marsh, Stonington, Connecticut. M.Sc, thesis, University of Connecticut, Storrs

Turner, R. E. (1976). Geographic variations in salt marsh macrophyte production: a review. Contrib. mar. Sci. 20: 47-68

Williams, T. M., Wolaver, T G., Dame, R. F., Spurrier, J. D. (1992). The Bly Creek ecosystem study — organic carbon transport within a euhaline salt marsh basin, North Inlet, South Carolina. J exp. mar. Biol. Ecol. 163: 125-139

Woodwell, G. M., Houghton, R. A., Hall, C. A. S., Whitney, D. E., Moll, R. E., Juers, D. W. (1979). The Flax Pond ecosystem study: exchanges of carbon in water between a salt marsh and Long Island Sound. Limnol. Oceanogr. 22: 833-838

Manuscript first received: June 21, 1994

Revised version accepted: January 4, 1995

This article was submitted to the editor 